\title{
The Effect of Microstructure on 3 Body Abrasive Wear Behavior of Hardfacing Alloys
}

\author{
K.M. KenchiReddy and C.T. Jayadeva
}

\begin{abstract}
Hardfacing is one of the most useful and economic ways to improve the performance of components submitted to severe wear conditions. A study was made to compare the microstructure and abrasion resistance of hardfacing alloys reinforced with primary chromium carbides, the hardfacing alloys were deposited onto M.S. plate by SMAW process.
\end{abstract}

Two different commercial hardfacing electrodes were employed to investigate the effect of the microstructure.The abrasion tests were carried out in a dry sand-rubber wheel abrasion machine according to the procedure A of ASTM G65 standard. Microstructure characterization and surface analysis were made using optical and scanning electron microscope. The result shows that the wear resistance is determined by the size, shape, distribution and chemical composition of the carbides, as well as by the matrix microstructure. The best abrasion resistance was obtained in microstructure composed of chromium carbide alloy. Hardfacing is a deposition of different metal over the parent metal to achieve required properties.

Keywords--- Abrasion Resistance, Hardfacing Alloys, Microstructure Characterization, Wear Mechanism

\section{INTRODUCTION}

$\mathrm{H}$ ARDFACING is a commonly employed method to improve surface properties of agriculture tools, components for mining operation, soil preparation equipments and earth moving equipments [1], [2]. An alloy is homogeneously deposits onto the surface of a soft material by welding, with the purpose of increasing loss in ductility and toughness of the substrate.

A wide variety of hardfacing alloys are commercially available for protection against wear. Deposits with a microstructure composed by disperse carbides in austenite matrix are extensively used for abrasion applications and are typically classified according to the expected hardness. Nevertheless, the abrasion resistance of a hardfacing alloys depends on many other factors such as the type, shape and distribution of hard phases, as well as the toughness and strain hardening behavior of the matrix [3]. Chromium-rich

Dr.K. M. Kenchi Reddy, Professor, Department of Mechanical Engineering, Sri Krishna Institute of Technology, Bengaluru, India. Email:kenreddy@rediffmail.com

Dr.C. T. Jayadeva, Professor, Department of Mechanical Engineering, Adichunchanagiri Institute of Technology, Chikmagalur, India. E-mail: ctjayadeva@yahoo.co.in electrodes are widely used due to low cost and availability; however, more expensive tungsten or vanadium-rich alloys offer better performance due to a good combination of hardness and toughness. Complex carbides electrodes are also used; especially when abrasive wear is accompanied by other wear mechanisms [4].

Several welding techniques such as oxyacetylene gas welding (OAW), gas metal arc welding (GMAW), shielded metal arc welding (SMAW) and submerged arc welding (SAW) can be used for hardfacing. The most importance differences among these techniques lie in the welding efficiency, the weld plate dilution and the manufacturing cost of welding consumables [5]. SMAW, for example, is commonly used due to the low cost of electrodes and easier application. The present investigation aims to study two commercial electrodes in terms of their chemical composition, microstructure, hardness and abrasive wear resistance.

\section{EXPERIMENTAL DETAILS}

\section{A. Base Metal}

The selection of base metal is very essential in deciding what alloy to use for hardfacing deposit. Since welding procedure differs according to the base metal. Mild steel was selected as the base metal for the study which composes the main elements of carbon, silicon, manganese, sulphur, and phosphorous. The chemical composition is given in Table 1.

\section{B. Hardfacing Alloys}

In the study, two different commercial hardfacing alloys were used for overlaying. These are basically iron - based alloys having varying amount of chromium, carbon, silicon and other alloying elements as they are more suitable for shielded metal arc welding process. Chemical compositions of two electrodes are presented in table 2. 
Table 1: Chemical Composition of Base Metal (In Weight Percentage)

\begin{tabular}{|c|c|c|c|c|c|}
\hline $\mathrm{C}$ & $\mathrm{Si}$ & $\mathrm{Mn}$ & $\mathrm{S}$ & $\mathrm{P}$ & $\mathrm{Fe}$ \\
\hline 0.18 & 0.32 & 1.47 & 0.013 & 0.029 & $\mathrm{Bal}$ \\
\hline
\end{tabular}

Table 2: Chemical Composition of Hardfacing Alloy (In Weight Percentages)

\begin{tabular}{|l|c|c|c|c|c|c|c|c|c|c|}
\hline Electrode & $\mathrm{C}$ & $\mathrm{Si}$ & $\mathrm{Mn}$ & $\mathrm{S}$ & $\mathrm{P}$ & $\mathrm{Cr}$ & $\mathrm{Mo}$ & $\mathrm{Ni}$ & $\mathrm{V}$ & $\mathrm{Fe}$ \\
\hline Hardfacing 1 & 0.33 & 0.28 & 1.15 & 0.014 & 0.025 & 2.22 & - & - & - & $\mathrm{Bal}$ \\
\hline Hardfacing 2 & 0.1 & 0.38 & 1.51 & 0.024 & 0.03 & 2.15 & 0.745 & 1.09 & 0.103 & $\mathrm{Bal}$ \\
\hline
\end{tabular}

\section{Welding Conditions}

The standard size of test specimens of 16 nos. with the dimensions of $250 \times 100 \times 12 \mathrm{~mm}$ was selected for the experiment.

The following precautions are taken before hardfacing:

- The electrodes are perfectly dried in the furnace and baked at $250^{\circ} \mathrm{C}$ one hour before the use

- Area of the weld is properly cleaned

- Preheated the hardfacing area to a minimum of $200^{\circ} \mathrm{C}$

A. Machine specifications

Name: TORNADO MIG 630 Arc welding machine

Current: $100-630$ A

Input Voltage: $415 \mathrm{~V} \pm 10 \%$ / 50-60 Hz / 3 Phase

Machine Capacity: 50 KVA

\section{Stages of Experiment}

The experiment was carried out in three stages to investigate the effect of welding parameters such as current, travel speed and voltage on hardfacing electrodes and the corresponding hardness was determined by using Vickers hardness testing machine.

1) In first stage, voltage (V) and travel speed (S) were kept constant and current (A) was increased [Table $3]$.

2) In second stage, voltage (V) and current (A) were kept constant and travel speed (S) was increased [Table 4].

3) In third stage, current (A) and travel speed (S) were kept constant and voltage (V) was increased [Table 5].

\section{RESULTS AND DISCUSSIONS}

\section{A. Dry sand abrasive test}

In the present study, sample of $75 \times 26 \times 6 \mathrm{~mm}$ size were used for testing as shown in figure 1 as per ASTMG65 standards. Specimens were ground using surface grinder to make the surface flat. Before the abrasive wear test all the specimens were cleaned with acetone and then weighed on an electronic balance with an accuracy of $\pm 0.1 \mathrm{mg}$.

The three-body abrasive wear tests were conducted using a dry sand/rubber wheel abrasion tester as per ASTM G65-04 (2010) shown in figure 2a. The sand particles of AFS 60 grade (figure 2b) were used as abrasives and they were angular in shape with sharp edges. The sand particles were sieved (size $200-250 \mu \mathrm{m}$ ), cleaned and dried in an oven for $6 \mathrm{hr}$ at $40{ }^{\circ} \mathrm{C}$. In this test, samples were held against a rotating rubber wheel under the constant flow of abrasives in between the sample and the rubber wheel under predetermined load. The actual photograph of the testing machine is shown in figure3.

\section{B. Test conditions}

Speed: $200 \pm 5 \mathrm{rpm}$

Sample test duration: 15 and $30 \mathrm{~min}$.

Abrasive: loose silica sand having particle size $200-250$ $\mu \mathrm{m}$

Load is kept constant at $130.5 \mathrm{~N}$ for all the samples. After each test, the samples were cleaned with acetone and then weighed on the electronic balance. The wear loss was calculated as weight losses in gms. 


\section{Stages of Experiment}

Table 3: Varying Current

\begin{tabular}{|c|c|c|c|c|}
\hline \multirow{2}{*}{ Electrode } & $\begin{array}{c}\text { Current } \\
(\mathbf{A})\end{array}$ & $\begin{array}{c}\text { Voltage } \\
(\mathbf{V})\end{array}$ & $\begin{array}{c}\text { Travel Speed } \\
(\mathbf{c m} / \mathbf{m i n})\end{array}$ & $\begin{array}{c}\text { Hardness } \\
(\mathbf{H V} \mathbf{0 . 5})\end{array}$ \\
\hline \multirow{3}{*}{ Hardfacing 1 } & 200 & 25 & 23.1 & 380 \\
\cline { 2 - 5 } & 250 & 25 & 23.1 & 318 \\
\cline { 2 - 5 } & 300 & 25 & 23.1 & 317 \\
\hline \multirow{3}{*}{ Hardfacing 2 } & 180 & 25 & 23.1 & 370 \\
\cline { 2 - 5 } & 200 & 25 & 23.1 & 416 \\
\cline { 2 - 5 } & 250 & 25 & 23.1 & 330 \\
\hline
\end{tabular}

Table 4: Varying Travel Speed

\begin{tabular}{|c|c|c|c|c|}
\hline \multirow{2}{*}{ Electrode } & $\begin{array}{c}\text { Travel speed } \\
(\mathbf{c m} / \mathbf{m i n})\end{array}$ & $\begin{array}{c}\text { Voltage } \\
(\mathbf{V})\end{array}$ & $\begin{array}{c}\text { Current } \\
(\mathbf{A})\end{array}$ & $\begin{array}{c}\text { Hardness } \\
(\mathbf{H V} \text { 0.5) }\end{array}$ \\
\hline \multirow{3}{*}{ Hardfacing 1 } & 15.0 & 25 & 200 & 417 \\
\cline { 2 - 5 } & 21.4 & 25 & 200 & 418 \\
\cline { 2 - 5 } & 50.0 & 25 & 200 & 356 \\
\hline \multirow{3}{*}{ Hardfacing 2 } & 16.67 & 25 & 200 & 377 \\
\cline { 2 - 5 } & 25.0 & 25 & 200 & 388 \\
\cline { 2 - 5 } & 50.0 & 25 & 200 & 406 \\
\hline
\end{tabular}

Table 5: Varying Voltage

\begin{tabular}{|c|c|c|c|c|}
\hline \multirow{2}{*}{ Electrode } & $\begin{array}{c}\text { Voltage } \\
\text { (V) }\end{array}$ & $\begin{array}{c}\text { Current } \\
\text { (A) }\end{array}$ & $\begin{array}{c}\text { Travel Speed } \\
(\mathbf{c m} / \mathbf{m i n})\end{array}$ & $\begin{array}{c}\text { Hardness } \\
\text { (HV 0.5) }\end{array}$ \\
\hline \multirow{2}{*}{ Hardfacing 1 } & 15 & 215 & 37.5 & 537 \\
\cline { 2 - 5 } & 25 & 215 & 37.5 & 390 \\
\hline \multirow{2}{*}{ Hardfacing 2 } & 15 & 215 & 37.5 & 401 \\
\cline { 2 - 5 } & 25 & 215 & 37.5 & 357 \\
\hline
\end{tabular}




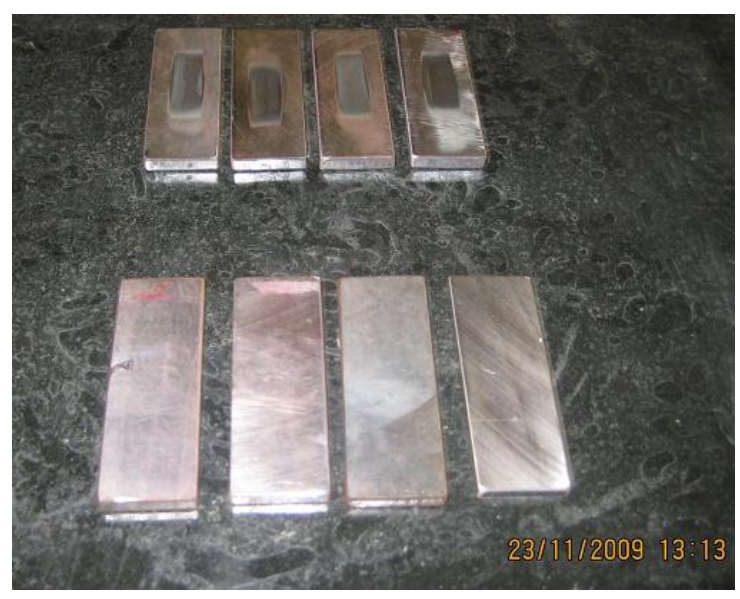

Figure 1: Standard Test Specimen $(75 \times 26 \times 6 \mathrm{~mm})$

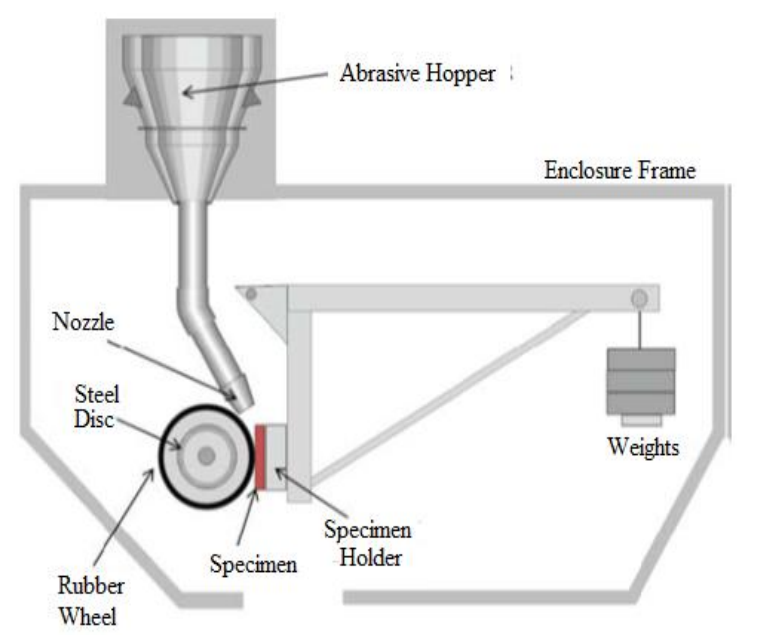

Figure 2(a): Dry Sand/Rubber Wheel Abrasion Tester

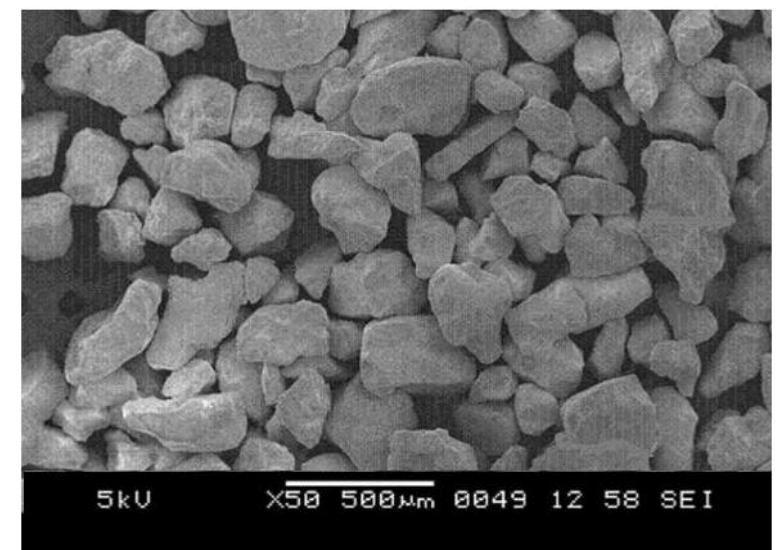

Figure 2(b): SEM Picture of Silica Sand (200-250 $\mu \mathrm{m})$

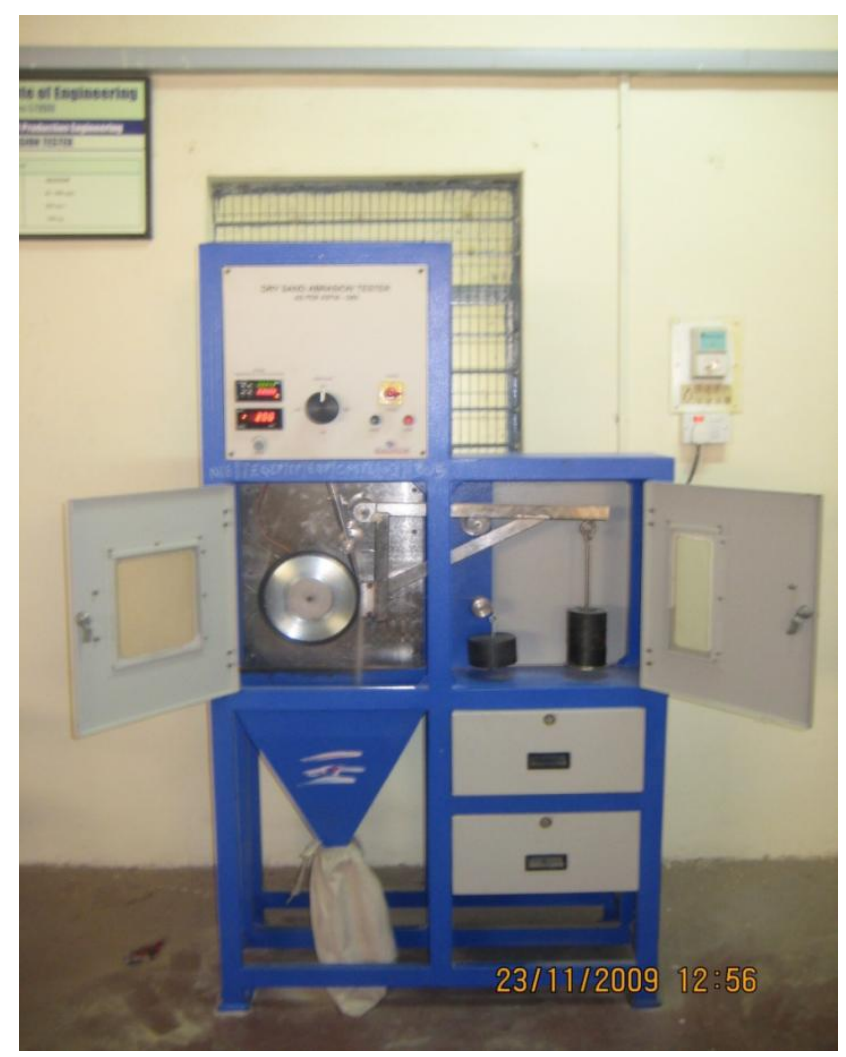

Figure 3: Dry Sand Abrasive Wear Testing Machine

In three-body abrasion, the sand particles behaved in one of the following ways. From free fall, the sand particles gained energy from the rubber wheel (figure 4a) and then struck the sample surface, which would result in the formation of pits. Secondly, the abrasive particles were embedded in the rubber wheel, transforming the three-body abrasion into multi-pass two-body abrasion (figure $4 \mathrm{~b}$ ). Thirdly, the particles roll at the interface causing plastic deformation to the hardfaced alloy (figure $4 \mathrm{c}$ ). These stages are illustrated in figure $4 \mathrm{a}-4 \mathrm{c}$ respectively.

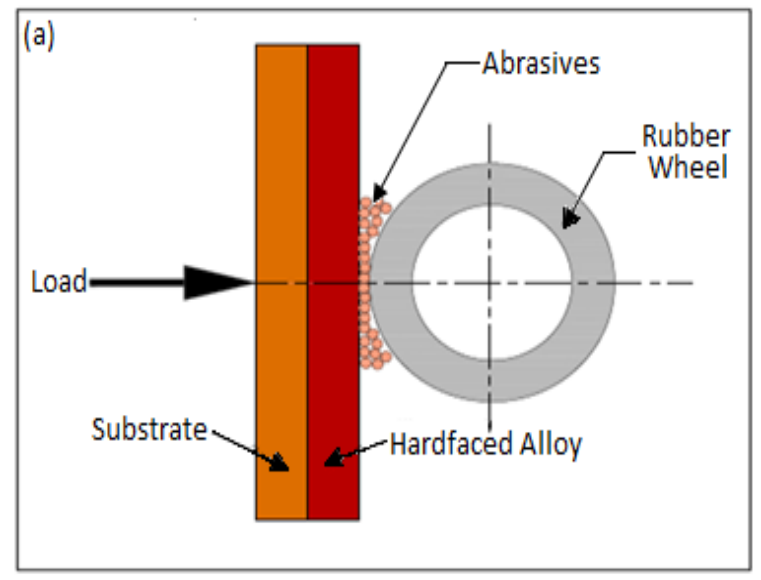



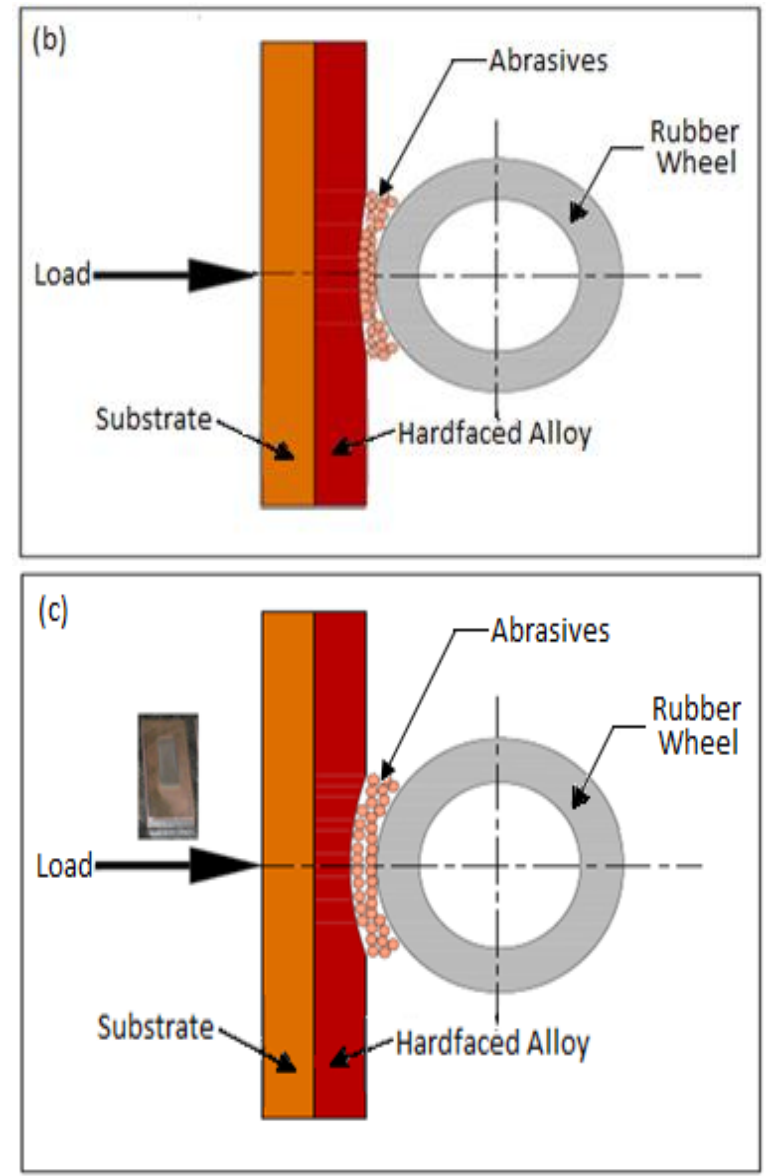

Figure 4: Stages of Abrasion: a) Initial, b) Middle and

c) End of Tests

Wear is generally a complex process, which is influenced by the many system variables, such as materials properties, environment and mode of loading. In this study, two Fe-Cr-C hardfaced alloys of different composition and microstructure were investigated under three-body abrasion.

Various researchers have been demonstrated that the application of hardfaced alloy on cast iron/mild steel significantly increases the surface hardness and results in increased resistance to abrasive wear [6]-[8], it has been shown in this work that the hardness of two hardfaced alloys were very different, their wear loss were dissimilar under the same test conditions. This indicates that the importance of microstructural parameters, such as the amount and size of the carbides, weld parameters, toughness and type of phases in determining the wear resistance [9]-[12].

The development of Fe-Cr-C hardfacings has been based around the understanding that good wear resistance is obtained with materials that have a high volume fraction of hard phases that are supported in a tough matrix. Both hardfacing 1 (type 1 electrode) and hardfacing 2 (type 2 electrode) are composed of similar phases; however, hardfacing 1 has a significantly larger amount of carbide phases than hardfacing 2.

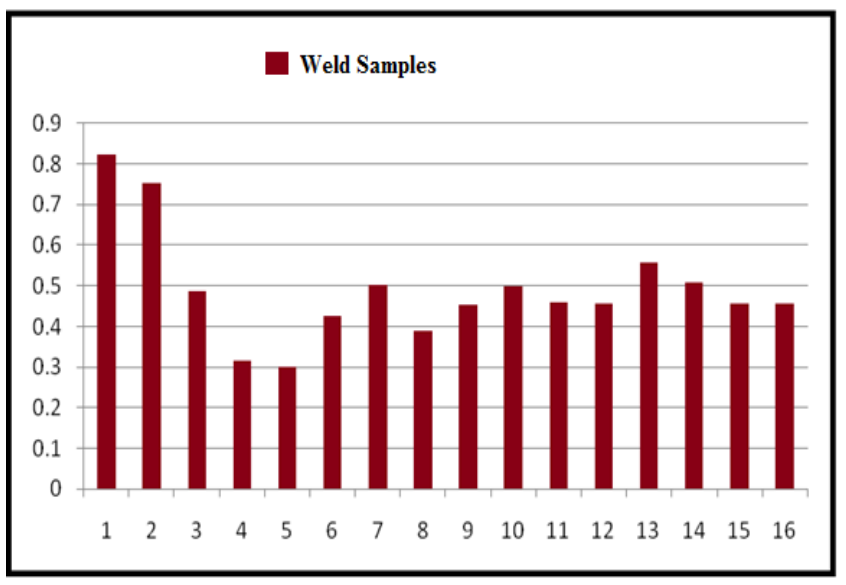

Figure 5: Wear Loss of Weld Sample 15 min

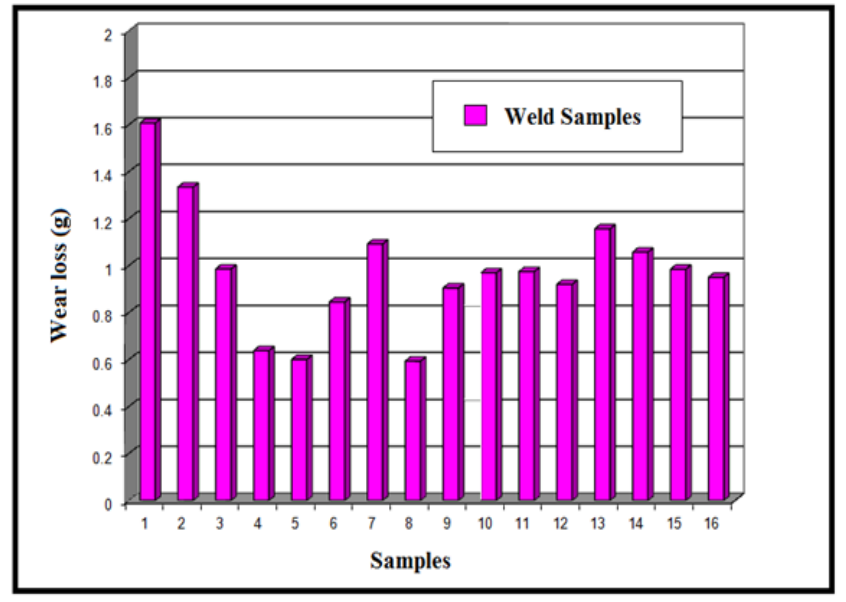

Figure 6: Wear Loss of Weld Samples $30 \mathrm{~min}$

The results indicate that as hardness increases, the loss of wear decreases (figures 5 and 6). Electrode-I has less wear as compared to electrode- 2 as the percentage of chromium, carbon and silicon are more in electrode-1. However the composition of chromium, carbon and silicon in the weld deposit made with type-1 electrode is higher than that of weld deposit made with type-2 electrode. Higher amount of chromium, carbon, silicon and finer structure resulted in higher hardness whereas lower hardness values were recorded in weld deposit with less amount of $\mathrm{Cr}, \mathrm{C}$ and $\mathrm{Si}$ and coarser structure.

The wear resistance increases with increase in chromium, carbon and silicon present in the hardfaced alloy 1. The experimental results are in agreement with those reported [9][11] on hardfacing alloys tested under low stress against a rubber wheel. Meanwhile, decrease in the wear resistance with decreasing chromium, carbon and silicon were observed in type 2 electrode and is in consistent with other published works. The reduction of the wear resistance with type 2 electrode could be due to the fact that the surface hardness was greatly reduced as compared to type 1 electrode. Higher hardness of samples increasing the apparent contact area allows a large number of sand particles to encounter the interface and share the stress. This, in turn, leads to a steady state or reduction in the wear rate. 
The wear test results of the type 1 electrode deposited hardfaced alloy indicate that a better wear performance. In type 2 electrode deposited hardfaced alloy, the wear resistance is poor compared to those obtained for type 1 hardfacing alloys. In type 2 electrode deposited hardfaced alloys, the abrasion was simultaneously initiated on the hard and soft phases of the weld material. In this situation, soft surface was continuously exposed to the interface throughout the entire test. It can be clearly seen from figures 5 and 6 that the presence of lower chromium and silicon in the interface increases the wear rate. On the other hand, in the case of the rich chromium, and silicon, the abrasion started through contact with the hard phase. This contributed to marginal damage and surface topography using atomic force microscopy (AFM) are as shown in figures 7 and 8 for type 1 electrode deposited samples (Samples 1 and 5).

Scanning probe microscopy constitutes a family of advanced techniques for surface analysis of hardfaced alloys. Although scanning probe microscopy was invented first, the current progress in scanning probe microscopy of metallic alloys for atomic force microscopy (AFM).

Surface roughness of metallic alloys affects the wear behaviour of hardfaced alloys. Therefore, in this work, before conducting the abrasive wear tests, selected sample surface topography were examined using AFM and the surface images of the samples are shown in figure 7 a and 8a respectively. The worn surface topography measured by AFM showed lower roughness values for type 1 electrode deposited hardfaced alloys (sample 5) and AFM images are shown in figure $8 \mathrm{~b}$ when compared to sample 1 (figure $7 \mathrm{~b}$ ). From these data it can be concluded that the damage is relatively low in sample 5 than that of sample 1 .

Scanning electron micrographs and surface topography by AFM taken from worn surfaces of the type 1 electrode deposited samples give an idea about the particular mechanisms involved in the wear process. Under the attack of irregular sand particles, the individual grains penetrate deeply into the surface of the sample investigated, subsequently removing material from the surface by an extensive microploughing process.

Mechanical properties influence the abrasive wear performance of a material. When considering the properties individually, it has been found that the hardness played a main role in controlling the abrasive wear [13]. The compression strength could have a stronger influence on the abrasive wear property than the tensile strength thereby the load is applied in the form of compression thereby pressing the specimen towards the sand particles at the interface [14]. This attracted the attention to explore the possibility of a correlation between the selected mechanical properties and the wear loss of the hardfaced alloys.

Table 6 and 7 shows the wear loss as well as the hardness of all the samples [Electrode 1 and Electrode 2]. From the table it can be seen that when considering the hardness alone, the wear resistance of all the hardfaced alloys tested, a better correlation was obtained in the present work. The higher the hardness, the lower was the wear loss [15]. From wear testing data under various conditions of the parameters, it can be stated that type 1 electrode deposited hardfaced alloys are more wear resistant than the type 2 electrode deposited hardfaced alloys.

The work summarizes that type 1 electrode deposited by considering optimum weld parameters i.e., current 200 Amps, travel speed of $21.3 \mathrm{~cm} / \mathrm{min}$ and potential difference of 15 volts of hardfaced alloys has beneficial effect on the threebody wear as well as on the hardness, thus re-emphasizing the fact that the introduction of rich $\mathrm{Cr}, \mathrm{C}$ and $\mathrm{Si}$ in type 1 electrode has got the advantage of enhancing the properties. 

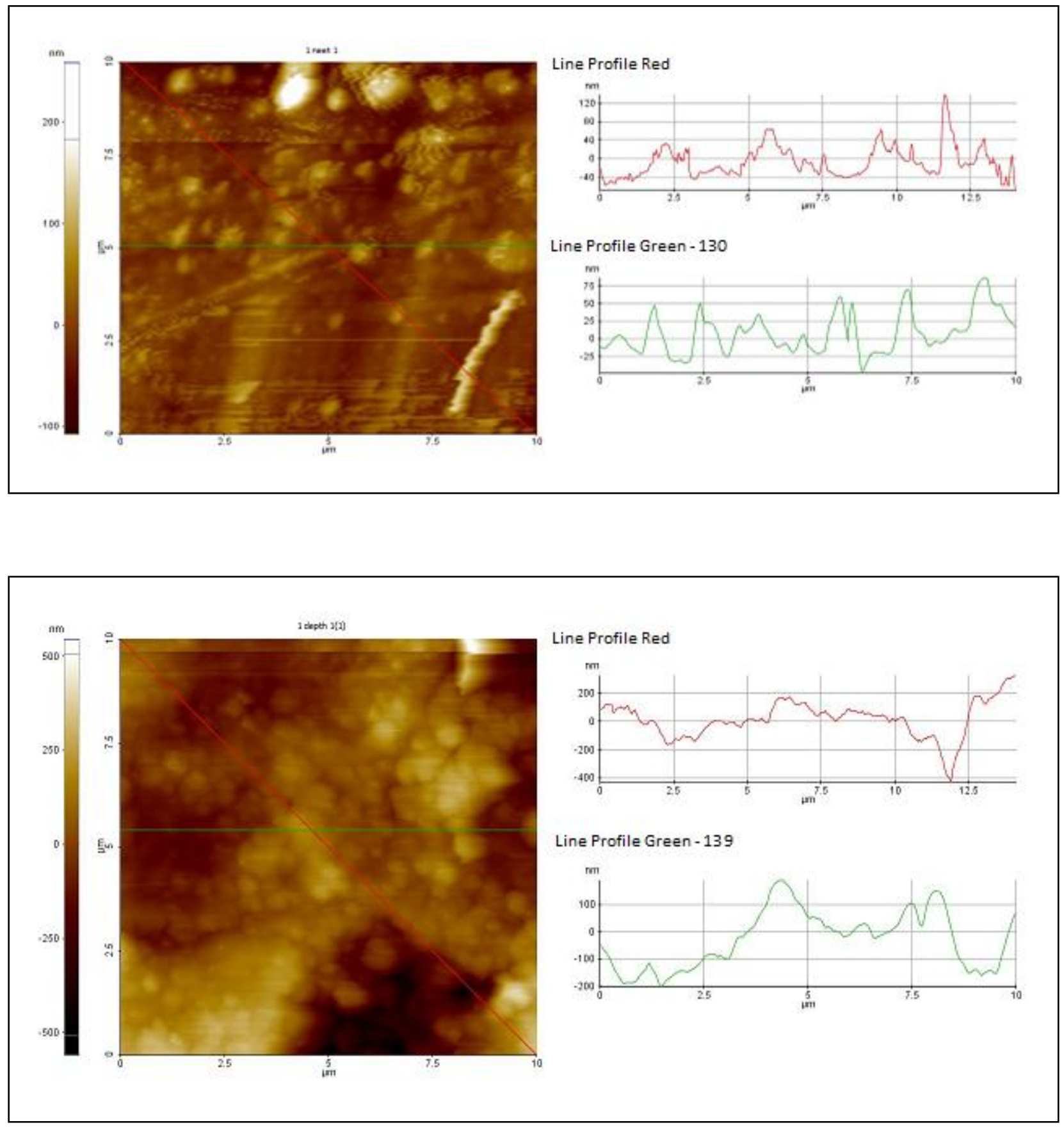

Figure 7: AFM Images for Type 1 Electrode Deposited Sample 1:

a) before Wear Test and b) After Wear Test 

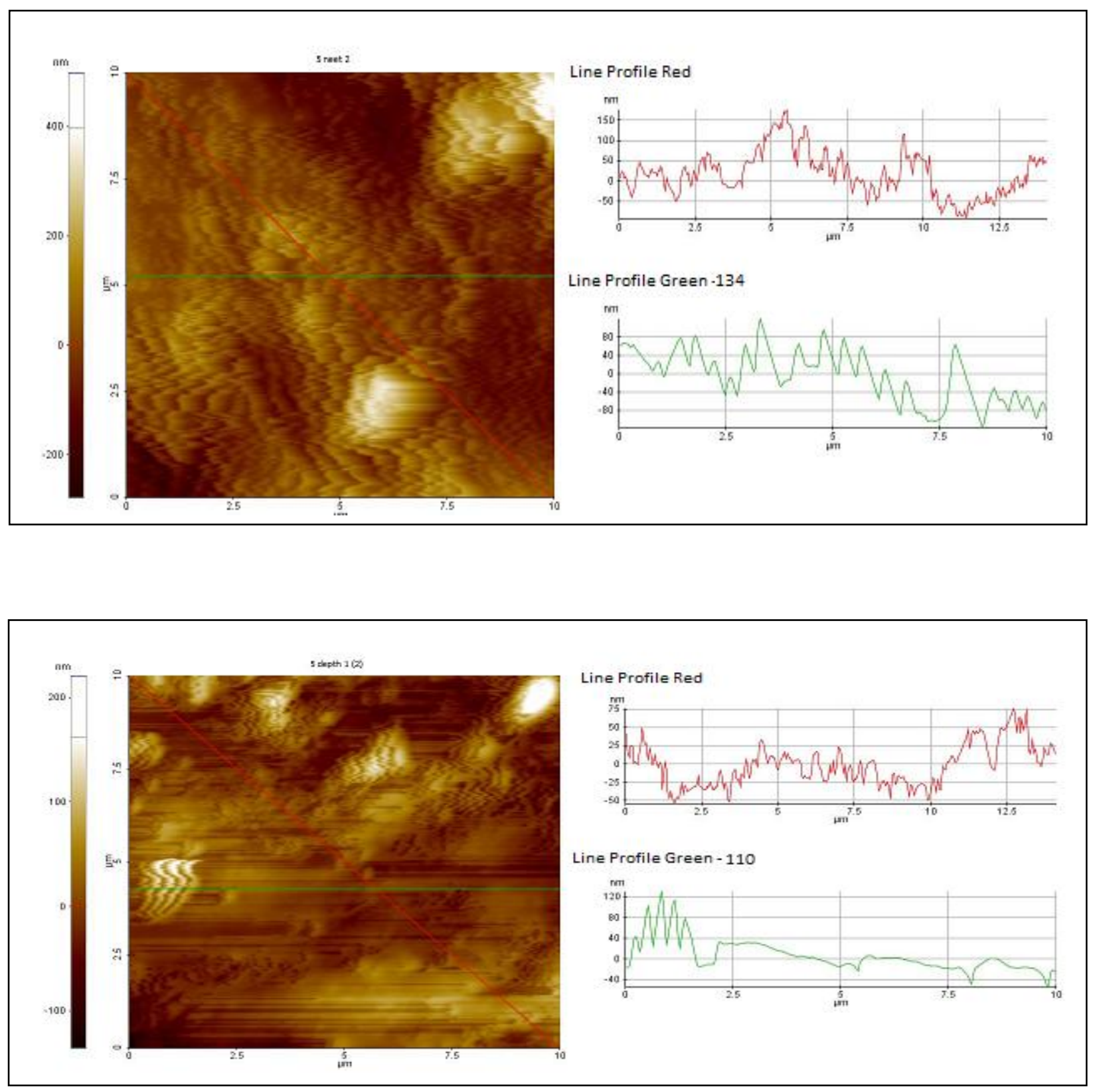

Figure 8: AFM Images for type 1 Electrode Deposited Sample 5:

a) before Wear Test and b) After Wear Test 
Table 6: The Relation between Hardness and Abrasion Resistance for Hardfacing 1(Electrode 1)

\begin{tabular}{|c|c|c|c|}
\hline Sample number & Load (N) & Weight loss (g) & Hardness (HV 0.5) \\
\hline 1 & 130.5 & 1.6075 & 377 \\
\hline 2 & 130.5 & 1.3345 & 380 \\
\hline 3 & 130.5 & 0.9861 & 417 \\
\hline 4 & 130.5 & 0.638 & 418 \\
\hline 5 & 130.5 & 0.6007 & 356 \\
\hline 6 & 130.5 & 0.8454 & 537 \\
\hline 7 & 130.5 & 1.0923 & 390 \\
\hline 8 & 130.5 & 0.5934 & \\
\hline
\end{tabular}

Table 7: The Relation between Hardness and Abrasion Resistance for Hardfacing 2(Electrode 2)

\begin{tabular}{|c|c|c|c|}
\hline Sample number & Load (N) & Weight loss (g) & Hardness (HV 0.5) \\
\hline 9 & 130.5 & 0.9051 & 330 \\
\hline 10 & 130.5 & 0.9698 & 376 \\
\hline 11 & 130.5 & 0.9746 & 406 \\
\hline 12 & 130.5 & 0.9205 & 388 \\
\hline 13 & 130.5 & 1.1571 & 377 \\
\hline 14 & 130.5 & 1.0576 & 357 \\
\hline 15 & 130.5 & 0.9852 & 401 \\
\hline 16 & 130.5 & 0.9506 & \\
\hline
\end{tabular}

\section{CONCLUSIONS}

ASTM G-65 is a reliable low stress abrasion test to assess the performance of the hardfacing deposits used in actual service conditions.

Results reveal that weld metal chemistry, welding heat input and test duration have significant influence on abrasion resistance. Hardness can be used as a predictor of wear resistance only for weld deposits having similar microstructural characteristics.

Wear resistance increases with increase in chromium, silicon and carbon content of weld deposit as well as with increase in heat input.

The hardness mainly depends on process parameters such as welding current, speed of arc travel and voltage.

\section{REFERENCES}

[1] P. Crook, "Friction and wear of hardfacing alloys", ASM Handbook, Friction, Lubrication and Wear Technology, vol. 18, pp. 758-762, 1992.

[2] I.M. Hutching, "Friction and Wear of Engineering Materials", Tribology, pp. 133-171, 1992.

[3] S. Chatterjee, T.K. Pal, "Wear behavior of hardfacing deposits on cast iron", Wear 255, pp. 417-425, 2003.

[4] S.H. Choo, C.K. Kim, K. Euh, S. Lee, J.Y. Jung, S. Alm, "Correlation of microstructure with the wear resistance and fracture toughness of hardfacing alloys reinforced with the complex carbides" Metall. Mater. Trans. A 31A, pp. 3041-3052, 2000.

[5] W. Wo, L.T. Wu, "The wear behavior between hardfacing materials", Metall. Mater. Trans. A 27A, pp. 3639-3648, 1996.

[6] R.S. Chandel, "Hardfacing consumables and their characteristics for mining and mineral processing industry", Indian Weld, pp. 26-34, 2001.

[7] H.S. Avery, H.J. Chapin, "Hard-facing alloys of the chromium carbide type, Weld , 31 (10) (1952) 917-930.G.L.F. Powell, The microstructure of hypereutectic $\mathrm{Cr}-\mathrm{C}$ hard surfacing deposits and its dependence on welding variables", Aust.Weld. Res. 6, pp. 16-23, 1979.

[8] D.J. Kotecki, J.S. Ogborn, "Abrasion resistance of iron-based hardfacing alloys", Weld, vol. 74 (8),pp 269-278. 1995.

[9] D.K. Dwivedi, "Microstructure and abrasive wear behaviour of iron base hardfacing", Mater. Sci. Technol, vol. 10, pp 1326-1330, 2004.

[10]O.N. Dogan, J.A. Hawk, G. Laird II, "Solidification structure and abrasion resistance of high chromium white irons", Metall. Mater. Trans. A 28A, pp. 1315-1328, 1997. 
[11]C.E.C. Rense, G.R. Edwards, H.R. Frost, "The effect of open-arc process variables on the microstructure and wear resistance of a typical chromium-carbide-type hardfacing deposit”, J. Mater. Energy Syst. 5 (3), pp. 149-159, 1983.

[12]H. Berns, A. Fischer, "Wear resistant of Fe-Cr-C hard surfacing weld deposits with additions of B, Ti and Mn, in: K.C. Ludema (Ed.)", Wear of Materials, ASME, New York, pp. 298-302, 1983.

[13]L.Xu and N.Kennon, "A Study of the Abrasive Wear of Carbon Steels", Wear, Vol 148, pp 101-112, 1991.

[14]R.Dasgupta, B.K.Prasad, A.K. Ja, O.P.Modi, S. Das, and A.H.Yegneswaram, " Wear Characteristics of a HardFaced Steel in Slurry", Wear, Vol 209, pp 255-262, 1997.

[15] Y.F. Zhou, Y.L. Yang, D. Li, J. Yang, Y.W. Jiang, X.J. Ren and Q.X. Yang, "Effect of Titanium Content on Microstructure and Wear Resistance of Fe-Cr-C Hardfacing Layers”, Vol 91, pp229-236, 2012.

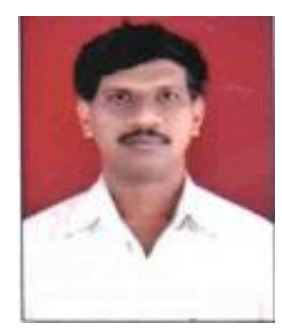

Dr.C. T Jayadeva is born in Karnataka, India on $18^{\text {th }}$ July 1963 . He earned his Undergraduate degree in Industrial and Production Engineering in 1986 from University of Mysore, Karnataka, Postgraduate degree in Industrial Engineering from university of Calicut,Kerala in the year 1993 and $\mathrm{Ph}, \mathrm{D}$ in Quality Management from VTU, Belgaum, India in the year 2008. He worked as Principal at Yagachi Institute of Technolgy, Hassan, Karnataka and presently working as Professor in the Department of Mechanical Engineering, AIT, Chikmaglur, Karnataka, He has published 24 papers in National/International conferences/journals. He is a Life Member of Indian Society for Technical Education.

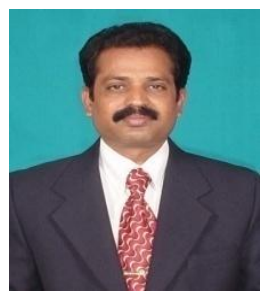

Dr.K.M.Kenchi Reddy is born in Karnataka, India on 4th August 1961. He earned his Undergraduate degree in Mechanical Engineering in 1986 from University of Mysore, Karnataka, India, Postgraduate degree in Production Engineering and System Technology from Mysore University in the year 1994 and Ph,D in Hardfacing on Mild Steel from VTU, Belgaum, India in the year 2013. Presently working as Professor in the Department of Mechanical Engineering, Sri Krishna Institute of Technology, Bengaluru. $\mathrm{He}$ has published 10 papers in National/International conferences/journals. $\mathrm{He}$ is a Life Member of Indian Society for Technical Education 